\title{
Leptin, hs-CRP, IL-18 and urinary protein before and after treatment of children with nephrotic syndrome
}

\author{
JIAYUN ZHOU, FENG SHI and WENLONG XUN \\ Department of Pediatrics, People's Hospital of Rizhao, Rizhao, Shandong 276800, P.R. China
}

Received December 19, 2017; Accepted February 20, 2018

DOI: $10.3892 /$ etm.2018.5923

\begin{abstract}
We aimed to analyze the changes in plasma leptin, serum inflammatory factors and urinary protein in children with nephrotic syndrome before and after treatment and their clinical significance. A total of 28 children treated and diagnosed with nephrotic syndrome between November 2015 and October 2016 were selected as treatment group, while 25 healthy children were selected as control group. There were no statistically significant differences in age, sex, body mass index (BMI), serum albumin and other general data between treatment group and control group $(\mathrm{P}>0.05)$. There was a positive correlation between serum high-sensitivity C-reactive protein (hs-CRP) level and $24 \mathrm{~h}$ urinary protein level in children with nephrotic syndrome before treatment $(\mathrm{r}=0.408, \mathrm{P}=0.005)$. Twenty-four hours urinary protein, urea nitrogen (BUN) and serum creatinine (SCr) levels in children with nephrotic syndrome before treatment were significantly higher than those in normal children, and these indexes were significantly decreased after treatment. The levels of plasma leptin and serum inflammatory factors (hs-CRP and IL-18) in children with nephrotic syndrome before treatment were obviously higher than those in normal children, and these indexes were obviously decreased after treatment. In conclusion, the detection of changes in plasma leptin, serum inflammatory factors (hs-CRP and IL-18) and urinary protein in children with nephrotic syndrome before and after treatment has important reference value for reflecting the severity of disease and evaluating the prognosis of children with nephrotic syndrome.
\end{abstract}

\section{Introduction}

Multiple causes lead to impaired glomerular filtration function, so that a large amount of albumin in plasma leak into the urine of patients, becoming a disease of albuminuria, which is called nephrotic syndrome, one of the more common diseases in the

Correspondence to: Dr Wenlong Xun, Department of Pediatrics, People's Hospital of Rizhao, 126 Tai'an Road, Rizhao, Shandong 276800, P.R. China

E-mail:w2u010@163.com

Key words: nephrotic syndrome, leptin, C-reactive protein, interleukin-18, urine protein pediatric urinary system (1). It is clinically believed that the pathogenesis of the disease is not yet very clear. Most of the views believe that it is related to the immune system dysfunction (2). Nephrotic syndrome is often accompanied by various infectious diseases due to immune dysfunction. A variety of cytokines related to immune regulation play a role in promoting the glomerular dysfunction in nephrotic syndrome (3). The overreaction of inflammatory system and overexpression of serum level of high-sensitivity C-reactive protein (hs-CRP) in children with nephrotic syndrome accelerates the inflammatory reaction process and further aggravates vascular endothelial injury (4). The load remodeling of renal blood vessels, the increased glomerular filtration rate and the increased urinary protein in patients aggravate the severity of nephrotic syndrome (5). In addition, the main treatment of nephrotic syndrome is to use hormones, but hormones often lead to varying degrees of obesity in children (6). In the human body, there is a polypeptide hormone leptin synthesized and secreted by fat cells, the main role of which is to regulate the body's lipid metabolism (7). It is closely related to the body weight of children and the severity of the disease, and it also affects the $24 \mathrm{~h}$ urinary protein quantitative in children (8). However, at present, the judgment of the patient's condition is not very clear through the detection of plasma leptin and serum inflammatory factors hs-CRP and interleukin-18 (IL-18) in children with nephrotic syndrome, and more evidence-based bases are needed to support it.

\section{Patients and methods}

General data. A total of 28 children diagnosed with nephrotic syndrome in People's Hospital of Rizhao (Rizhao, China) from November 2015 to October 2016 were selected as the treatment group, another 25 healthy children were selected as the control group, including 30 males and 23 females aged 5-13 years old with an average age of $8.56 \pm 2.72$ years old. By collecting the patients' age, sex, serum albumin and other basic data, all patients included in the treatment group were diagnosed with nephrotic syndrome according to the About Clinical Classification, Diagnosis and Treatment Recommendation of Glomerular Diseases in Children designated by Chinese Medical Association of Pediatrics in 2000. Exclusion criteria: child patients aged over 14 years old; child patients with first-onset nephrotic syndrome; patients with no history of recurrence and without treatment with glucocorticoids or drugs related to mediation of immunity prior to treatment; tumor 
patients; patients with severe circulatory system, metabolic system, urinary system, or immune system diseases; patients who exited midway or had incomplete clinical data. This study was approved by the Ethics Committee of People's Hospital of Rizhao. Signed written informed consents were obtained from the parents/guardians of all patients before the study.

Methods. Children with nephrotic syndrome received routine treatment after admission, of which the most important was the treatment with hormones and immunosuppressive agents with the whole course of treatment of 8-10 weeks, while children in the healthy control group did not received any treatment. Detection of the plasma leptin levels, inflammatory factors and renal function: $20 \mathrm{ml}$ of morning fasting peripheral venous blood was collected from patients in the treatment group on the day before treatment. The leptin level was measured by radioimmunoassay, the levels of hs-CRP and IL-18 were measured by immunoturbidimetry, the levels of blood urea nitrogen (BUN) and serum creatinine ( $\mathrm{SCr}$ ) were measured by enzyme-linked immunosorbent assay (ELISA). Meanwhile, levels of serum leptin, hs-CRP, IL-18, BUN and $\mathrm{SCr}$ of patients in the control group were also determined by the same method at the same time. Moreover, the levels of serum leptin, hs-CRP, IL-18, BUN and SCr of patients in the treatment group were also determined by the same method at 2 weeks, 3 months and 6 months after treatment. The kits were supplied by the Bender (Vienna, Austria).

Detection of urinary protein: $24 \mathrm{~h}$ urine specimens of patients in the treatment group were collected one day before the treatment, and the $24 \mathrm{~h}$ urinary protein quantitative was calculated. Meanwhile, the $24 \mathrm{~h}$ urinary protein quantitative of patients in the control group was detected by the same method at the same time. Moreover, the $24 \mathrm{~h}$ urinary protein of patients in the treatment group was quantified by the same method at 2 weeks, 3 months and 6 months after treatment.

Statistical analysis. The data were processed by SPSS 19.0 software (IBM, Armonk, NY, USA), collection data were expressed by mean $\pm \mathrm{SD}$, enumeration data were compared by $\chi^{2}$ test, correlation analysis was used for two factors, and $\mathrm{P}<0.05$ suggested that the difference was statistically significant.

\section{Results}

Comparisons of general conditions between the treatment group and the control group before treatment. There were no statistically significant differences in the age, sex, body mass index (BMI) and serum albumin between the treatment group and the control group before treatment $(\mathrm{P}>0.05)$, and the data were comparable (Table I).

Correlation analysis of inflammatory factors and $24 \mathrm{~h}$ urinary protein in treatment group before treatment. The serum hs-CRP factor level in the treatment group before treatment was positively correlated with the $24 \mathrm{~h}$ urinary protein level $(r=0.408, P=0.005)$, with statistical significance (Fig. 1).

Comparison of peripheral plasma leptin levels between the treatment group and the control group before treatment, and at 2 weeks, 3 months and 6 months after treatment. The plasma
Table I. Comparisons of general data between the treatment group and the control group before treatment.

\begin{tabular}{lccc}
\hline & $\begin{array}{c}\text { Treatment } \\
\text { group } \\
(\mathrm{n}=28)\end{array}$ & $\begin{array}{c}\text { Control } \\
\text { group } \\
(\mathrm{n}=25)\end{array}$ & P-value \\
\hline Age (years) & $8.38 \pm 1.96$ & $8.72 \pm 2.05$ & 0.871 \\
Sex (male/female) & $16 / 12$ & $14 / 11$ & 0.905 \\
BMI $\left(\mathrm{kg} / \mathrm{m}^{2}\right)$ & $22.43 \pm 5.71$ & $20.78 \pm 4.93$ & 0.059 \\
Serum albumin $(\mathrm{g} / \mathrm{l})$ & $17.72 \pm 2.75$ & $17.82 \pm 3.91$ & 0.051 \\
\hline
\end{tabular}

Table II. Comparison of leptin levels between the treatment group and the control group before treatment, at 2 weeks, 3 months and 6 months after treatment.

\begin{tabular}{lc}
\hline Group & Leptin $(\mu \mathrm{g} / \mathrm{l})$ \\
\hline Control group $(\mathrm{n}=25)$ & $9.26 \pm 2.89$ \\
Treatment group $(\mathrm{n}=28)$ & \\
Before treatment & $29.78 \pm 5.95$ \\
After treatment & \\
2 weeks & $20.81 \pm 3.41$ \\
3 months & $13.17 \pm 2.57$ \\
6 months & $10.08 \pm 1.26$
\end{tabular}

i) Compared with the same group before treatment, $\mathrm{P}<0.01$; ii) compared with the control group before treatment, $\mathrm{P}<0.01$; iii) compared with the control group 6 months after treatment, $\mathrm{P}>0.05$

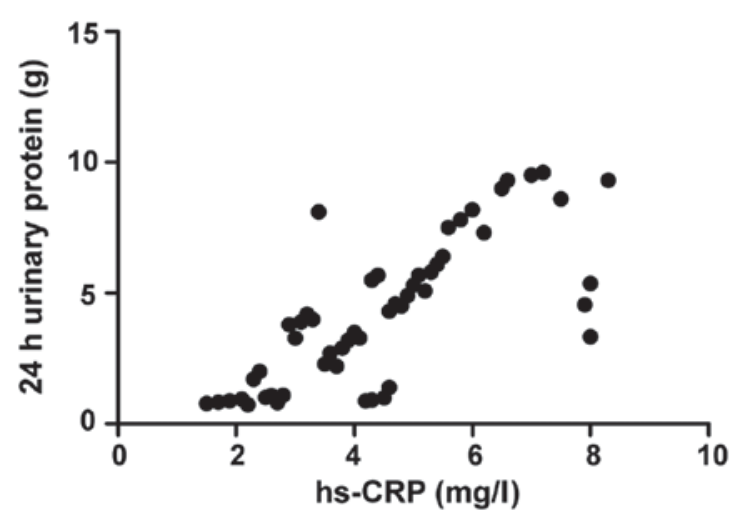

Figure 1. Correlation between high-sensitivity C-reactive protein (hs-CRP) and $24 \mathrm{~h}$ urinary protein.

leptin level in the treatment group was significantly higher before treatment than that in the control group, significantly lower at 2 weeks after treatment than that before treatment, significantly lower at 3 months after treatment than that at 2 weeks after treatment, and significantly lower at 6 months after treatment than that at 2 weeks after treatment and before treatment, and the differences were statistically significant $(\mathrm{P}<0.05)$; there was no significant difference in plasma leptin level between the treatment group and the healthy control group at 6 months after treatment $(\mathrm{P}>0.05)$ (Table II). 

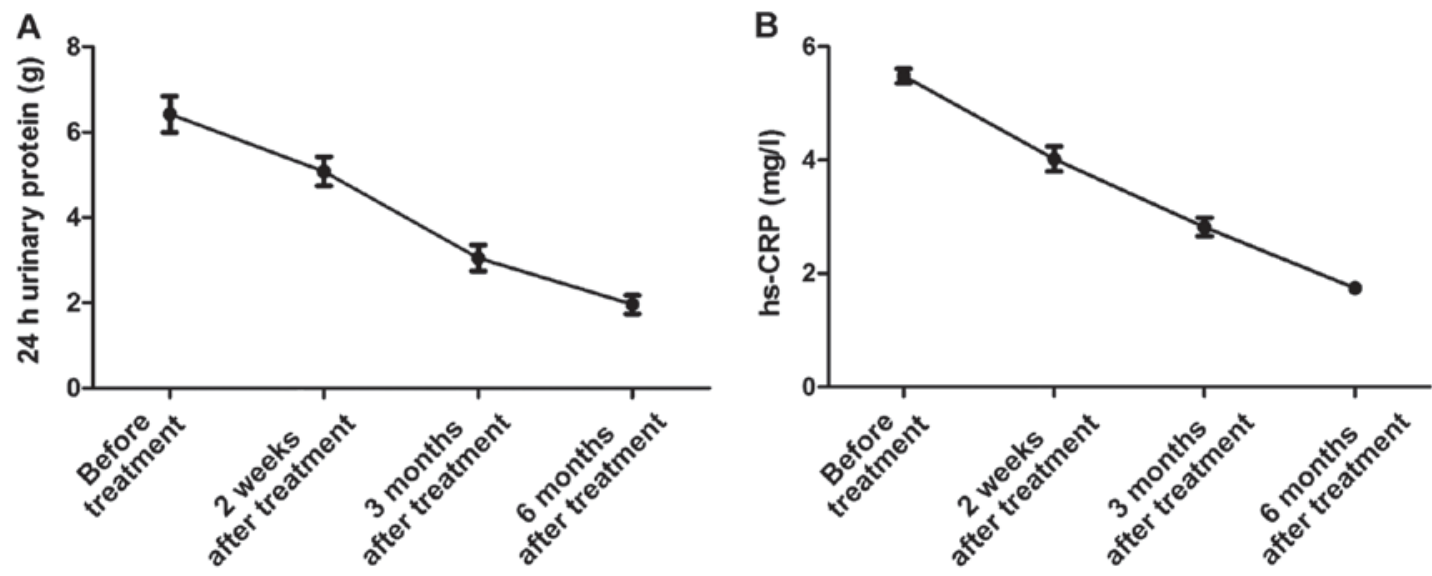

Figure 2. The trends of $24 \mathrm{~h}$ urinary protein (A) and high-sensitivity C-reactive protein (hs-CRP) (B) in the treatment group before treatment, and at 2 weeks, 3 months and 6 months after treatment.

Table III. Comparison of the levels of hs-CRP and IL-18 between the treatment group and the control group before treatment, at 2 weeks, 3 months and 6 months after treatment.

\begin{tabular}{lcc}
\hline Group & hs-CRP $(\mathrm{mg} / \mathrm{l})$ & $\mathrm{IL}-18(\mathrm{pg} / \mathrm{ml})$ \\
\hline $\begin{array}{l}\text { Control group }(\mathrm{n}=25) \\
\text { Treatment group }(\mathrm{n}=28)\end{array}$ & $2.05 \pm 0.94$ & $39.16 \pm 0.17$ \\
$\quad$ Before treatment & $5.36 \pm 1.54$ & $59.63 \pm 15.02$ \\
After treatment & & \\
2 weeks & $4.07 \pm 1.36$ & $52.39 \pm 11.22$ \\
3 months & $2.95 \pm 0.98$ & $43.61 \pm 4.16$ \\
6 months & $2.11 \pm 0.53$ & $39.15 \pm 2.79$ \\
\hline
\end{tabular}

i) Compared with the same group before treatment, $\mathrm{P}<0.01$; ii) compared with the control group before treatment, $\mathrm{P}<0.01$; iii) compared with the control group 6 months after treatment, P>0.05. hs-CRP, high-sensitivity C-reactive protein; IL-18, interleukin-18.

Comparisons of the levels of hs-CRP and IL-18 in peripheral blood serum between the treatment group and the control group before treatment, and at 2 weeks, 3 months and 6 months after treatment. The levels of peripheral serum inflammatory factors hs-CRP and IL-18 in the treatment group were significantly higher before treatment than those in the control group, significantly lower at 2 weeks after treatment than those before treatment,significantly lower at 3 months after treatment than those at 2 weeks after treatment, and significantly lower at 6 months after treatment than those at 2 weeks after treatment and before treatment, and the differences were statistically significant $(\mathrm{P}<0.05)$; the levels of inflammatory factors in the treatment group at 6 months after treatment were not significantly different from those in the healthy control group $(\mathrm{P}>0.05)$ (Table III).

Comparisons of the levels of 24 h urinary protein, serum BUN and $\mathrm{SCr}$ between the treatment group and the control group before treatment, and at 2 weeks, 3 months and 6 months after treatment. The levels of $24 \mathrm{~h}$ urinary protein, BUN and $\mathrm{SCr}$ in the treatment group were significantly higher before treatment than those in the control group,significantly lower at 2 weeks
Table IV. Comparison of $24 \mathrm{~h}$ urinary protein, $\mathrm{BUN}$ and $\mathrm{SCr}$ between the treatment group and the control group before treatment, at 2 weeks, 3 months and 6 months after treatment.

\begin{tabular}{lccc}
\hline Group & $\begin{array}{c}\text { 24 h urinary } \\
\text { protein }(\mathrm{g})\end{array}$ & $\begin{array}{c}\text { BUN } \\
(\mathrm{mmol} / \mathrm{l})\end{array}$ & $\begin{array}{c}\mathrm{SCr} \\
(\mu \mathrm{mmol} / \mathrm{l})\end{array}$ \\
\hline $\begin{array}{l}\text { Control group }(\mathrm{n}=25) \\
\text { Treatment group }(\mathrm{n}=28) \\
\text { Before treatment }\end{array}$ & $1.01 \pm 0.23$ & $4.32 \pm 0.88$ & $63.58 \pm 14.4$ \\
$\begin{array}{l}\text { After treatment } \\
\text { 2 weeks }\end{array}$ & $6.32 \pm 2.57$ & $7.09 \pm 4.14$ & $115.76 \pm 22.56$ \\
3 months & $5.08 \pm 1.98$ & $6.01 \pm 3.82$ & $90.31 \pm 18.25$ \\
6 months & $3.02 \pm 1.14$ & $4.93 \pm 3.61$ & $79.54 \pm 9.57$ \\
& $1.31 \pm 0.98$ & $4.34 \pm 1.27$ & $64.37 \pm 10.63$ \\
\end{tabular}

i) Compared with the same group before treatment, $\mathrm{P}<0.01$; ii) compared with the control group before treatment, $\mathrm{P}<0.01$; iii) compared with the control group 6 months after treatment, $\mathrm{P}>0.05$. BUN, urea nitrogen; $\mathrm{SCr}$, serum creatinine.

after treatment than those before treatment, significantly lower at 3 months after treatment than those at 2 weeks after treatment, and significantly lower at 6 months after treatment than those at 2 weeks after treatment and before treatment, and the differences were statistically significant $(\mathrm{P}<0.05)$; there were no significant differences in $24 \mathrm{~h}$ urinary protein, BUN and $\mathrm{SCr}$ levels between the treatment group and the healthy control group at 6 months after treatment $(\mathrm{P}>0.05)$ (Table IV).

The trends of serum hs-CRP and $24 \mathrm{~h}$ urinary protein in the treatment group before treatment, and at 2 weeks, 3 months and 6 months after treatment. The serum inflammatory factors levels and $24 \mathrm{~h}$ urinary protein in the treatment group before treatment, and at 2 weeks, 3 months and 6 months after treatment showed decreasing trends (Fig. 2).

\section{Discussion}

Glomerular dysfunction caused by different reasons may lead to nephrotic syndrome. Because the pathological type 
of the disease is numerous, and the mechanism is not very clear (9), it often brings difficulties to clinicians in the treatment. The most common clinical manifestation is low serum protein level due to leakage of urinary protein, generally below 3.5 grams (10). If the patient is in a low-protein state for a long time, the colloid osmotic pressure in the human body will decrease, and the patient will then have symptoms such as edema (11). In pediatric urinary system, nephrotic syndrome is one of the common diseases, whose main treatment is to use hormones and immunosuppressive agents (12). Numerous research data have shown that the plasma leptin level is closely related to the severity of impaired renal function, and the more serious the renal function damage is, the higher the plasma leptin level is (13). This study found that the plasma leptin level in children with nephrotic syndrome was significantly higher than that in the healthy control group, and significantly lower after treatment than that before treatment. The leptin level after 6 months of treatment was not significantly different from that in the healthy control group, which was consistent with numerous research data. The main reason for the increased leptin in nephrotic syndrome is the decreased glomerular filtration rate (14). Second, impaired immune function in children, deficiency of complement factors, and low serum protein malnutrition and many other factors will lead to an increase in plasma leptin level in children with nephrotic syndrome (15).

On the other hand, in the immune system, IL-18 plays an important role in maintaining the balance of the immune system (16). Mononuclear macrophages, B cells, killer cells and other factors in the human body can synthesize and secrete IL-18, and IL-18, in turn, can promote the macrophage and other response. These immune cells will cause damage to the immune response of the kidney to some extent (17). At the same time, the overreaction of inflammatory system and overexpression of hs-CRP in children with nephrotic syndrome lead to the deformation of vascular endothelial tissue cells and an increase of resistance (18). hs-CRP can also lead to the production and secretion of angiotensin receptor and vascular endothelium-secreting plasminogen activator inhibitor, resulting in different degrees of hardening of arteries (19), deposited on vascular endothelial cells in the form of immune complexes, causing the release of another inflammatory factor in the process of attacking vascular endothelium, and eventually leading to renal vascular damage, glomerular filtration dysfunction, impaired renal function and $24 \mathrm{~h}$ urinary protein quantitative increase. This study concluded that the levels of inflammatory factors in children with nephrotic syndrome before treatment were significantly higher than those in children in the healthy control group, and significantly lower after treatment than those before treatment. From the correlation analysis, and the change trends of inflammatory factors and $24 \mathrm{~h}$ urinary protein before and after treatment, it can be seen that the higher levels of inflammatory factors in children with nephrotic syndrome, the more serious damage to the kidneys.

In conclusion, the detection of plasma leptin, serum inflammatory factors hs-CRP and IL-18 levels in children with nephrotic syndrome is crucial for the judgment of the severity of disease, and it is of important reference value in improving the treatment and prognosis of children with nephrotic syndrome.

\section{Acknowledgements}

Not applicable.

\section{Funding}

No funding was received.

\section{Availability of data and materials}

All data generated or analyzed during this study are included in this published article.

\section{Authors' contributions}

JZ designed the study and prepared the manuscript. FS collected the data. WX analysed the data. All authors read and approved the final manuscript.

\section{Ethics approval and consent to participate}

This study was approved by the Ethics Committee of People's Hospital of Rizhao (Rizhao, China). Signed written informed consents were obtained from the parents/guardians of all patients before the study.

\section{Consent for publication}

Not applicable.

\section{Competing interests}

The authors declare that they have no competing interests.

\section{References}

1. Landt M, Ludbrook PA and Billadello JJ: Role of protein binding in renal elimination of leptin. Clin Endocrinol (Oxf) 59: 44-48, 2003.

2. Yao H,Cai ZY and Sheng ZX: NAC attenuates adriamycin-induced nephrotic syndrome in rats through regulating TLR4 signaling pathway. Eur Rev Med Pharmacol Sci 21: 1938-1943, 2017.

3. Daschner M, Tönshoff B, Blum WF, Englaro P, Wingen AM, Schaefer F, Wühl E, Rascher W and Mehls O; European Study Group for Nutritional Treatment of Chronic Renal Failure in Childhood: Inappropriate elevation of serum leptin levels in children with chronic renal failure. J Am Soc Nephrol 9: 1074-1079, 1998.

4. Yoshida T, Momotani N, Hayashi M, Monkawa T, Ito K and Saruta T: Serum leptin concentrations in patients with thyroid disorders. Clin Endocrinol (Oxf) 48: 299-302, 1998.

5. Bakr A, Shokeir M, El-Chenawi F, El-Husseni F, AbdelRahman A and El-Ashry R: Tumor necrosis factor-alpha production from mononuclear cells in nephrotic syndrome. Pediatr Nephrol 18: 516-520, 2003.

6. Florian M, Florianova L, Hussain S and Magder S: Interaction of estrogen and tumor necrosis factor alpha in endothelial cell migration and early stage of angiogenesis. Endothelium 15: $265-275,2008$

7. Matsumoto K and Kanmatsuse K: Elevated interleukin-18 levels in the urine of nephrotic patients. Nephron 88: 334-339, 2001.

8. Drewe E, McDermott EM and Powell RJ: Treatment of the nephrotic syndrome with etanercept in patients with the tumor necrosis factor receptor-associated periodic syndrome. N Engl J Med 343: 1044-1045, 2000

9. Reinehr T, Kratzsch J, Kiess W and Andler W: Circulating soluble leptin receptor, leptin, and insulin resistance before and after weight loss in obese children. Int J Obes 29: 1230-1235, 2005. 
10. Lányi E, Csernus K, Erhardt E, Tóth K, Urbán B, Lénárd L and Molnár D: Plasma levels of acylated ghrelin during an oral glucose tolerance test in obese children. J Endocrinol Invest 30: 133-137, 2007.

11. Schroth M, Kratzsch J, Gröschl M, Rauh M, Rascher W and Dötsch J: Increased soluble leptin receptor in children with nephrotic syndrome. J Clin Endocrinol Metab 88: 5497-5501, 2003.

12. Schroth M, Gröschl M, Dörr HG, Blum WF, Rascher W and Dötsch J: Renal loss of leptin in patients with nephrotic syndrome. Eur J Endocrinol 145: 463-468, 2001.

13. Garcia GE, Xia Y, Ku G, Johnson RJ, Wilson CB and Feng L: IL-18 translational inhibition restricts IFN-gamma expression in crescentic glomerulonephritis. Kidney Int 64: 160-169, 2003.

14. Nguyen MT and Devarajan P: Biomarkers for the early detection of acute kidney injury. Pediatr Nephrol 23: 2151-2157, 2008.

15. Washburn KK, Zappitelli M, Arikan AA, Loftis L, Yalavarthy R, Parikh CR, Edelstein CL and Goldstein SL: Urinary interleukin-18 is an acute kidney injury biomarker in critically ill children. Nephrol Dial Transplant 23: 566-572, 2008.

16. Araya C, Diaz L, Wasserfall C, Atkinson M, Mu W, Johnson R and Garin E: T regulatory cell function in idiopathic minimal lesion nephrotic syndrome. Pediatr Nephrol 24: 1691-1698, 2009.
17. Wakkach A, Augier S, Breittmayer JP, Blin-Wakkach C and Carle GF: Characterization of IL-10-secreting T cells derived from regulatory $\mathrm{CD} 4{ }^{+} \mathrm{CD} 25^{+}$cells by the TIRC7 surface marker. J Immunol 180: 6054-6063, 2008.

18. Barrat FJ, Cua DJ, Boonstra A, Richards DF, Crain C, SavelkoulHF, de Waal-MalefytR, Coffman RL,Hawrylowicz CM and $\mathrm{O}^{\prime} \mathrm{Garra} \mathrm{A}$ : In vitro generation of interleukin 10-producing regulatory CD4(+) T cells is induced by immunosuppressive drugs and inhibited by T helper type 1 (Th1)- and Th2-inducing cytokines. J Exp Med 195: 603-616, 2002.

19. Kiliś-Pstrusińska K, Medyńska A, Zwolińska D and Wawro A Interleukin-18 in urine and serum of children with idiopathic nephrotic syndrome. Kidney Blood Press Res 31: 122-126, 2008.

(i) $\Theta$ This work is licensed under a Creative Commons Attribution-NonCommercial-NoDerivatives 4.0 International (CC BY-NC-ND 4.0) License. 